\title{
Glyco-engineering for biopharmaceutical production in moss bioreactors
}

\author{
Eva L. Decker ${ }^{1}$ *, Juliana Parsons ${ }^{1}$ and Ralf Reski ${ }^{1,2,3}$ \\ ${ }^{1}$ Department of Plant Biotechnology, Faculty of Biology, University of Freiburg, Freiburg, Germany \\ 2 BIOSS Centre for Biological Signalling Studies, Freiburg, Germany \\ ${ }^{3}$ Freiburg Institute for Advanced Studies, Freiburg, Germany
}

\section{Edited by:}

Nausicaä Lannoo, Ghent University, Belgium

\section{Reviewed by:}

Markus Pauly, University of California, Berkeley, USA

Richard Strasser, University of Natural Resources and Life Sciences, Austria

\section{*Correspondence:}

Eva L. Decker, Department of Plant Biotechnology, Faculty of Biology,

University of Freiburg,

Schaenzlestraße 1, 79104 Freiburg

Germany

e-mail:eva.decker@biologie.unifreiburg.de
The production of recombinant biopharmaceuticals (pharmaceutical proteins) is a strongly growing area in the pharmaceutical industry. While most products to date are produced in mammalian cell cultures, namely Chinese hamster ovary cells, plant-based production systems gained increasing acceptance over the last years. Different plant systems have been established which are suitable for standardization and precise control of cultivation conditions, thus meeting the criteria for pharmaceutical production. The majority of biopharmaceuticals comprise glycoproteins. Therefore, differences in protein glycosylation between humans and plants have to be taken into account and plant-specific glycosylation has to be eliminated to avoid adverse effects on quality, safety, and efficacy of the products. The basal land plant Physcomitrella patens (moss) has been employed for the recombinant production of high-value therapeutic target proteins (e.g., Vascular Endothelial Growth Factor, Complement Factor H, monoclonal antibodies, Erythropoietin). Being genetically excellently characterized and exceptionally amenable for precise gene targeting via homologous recombination, essential steps for the optimization of moss as a bioreactor for the production of recombinant proteins have been undertaken. Here, we discuss the glyco-engineering approaches to avoid non-human $\mathrm{N}$ - and O-glycosylation on target proteins produced in moss bioreactors.

Keywords: Physcomitrella patens, moss bioreactor, plant-made pharmaceuticals, glycosylation, posttranslational modifications

\section{INTRODUCTION}

Biopharmaceuticals are indispensable in modern medicine. In 2010 more than 200 biopharmaceuticals were available on the market and around 10-20 more are approved every year (Walsh, 2010a). As the biggest group of biopharmaceuticals consists of pharmaceutical recombinant proteins, this term is often used as a synonym for the former. The biochemical and pharmacological properties of a protein are not only determined by its amino acid sequence but also largely influenced by a palette of modifications that proteins undergo co- or posttranslationally (Mann and Jensen, 2003), usually grouped together and referred to as posttranslational modifications (PTMs). Common PTMs found in pharmaceutical proteins are glycosylation, hydroxylation, carboxylation, amidation, sulfatation, disulfide bond formation, and proteolytic processing (Walsh and Jefferis, 2006). Among these, glycosylation is the most frequent PTM, being present in at least $40 \%$ of the pharmaceutical recombinant proteins available on the market (Walsh, 2010b). The presence and quality of glycosylation plays a crucial role for the pharmacological properties of a therapeutic protein by influencing protein folding and stability, serum half-life, in vivo activity, pharmacokinetics, and immunogenicity (Li and d'Anjou, 2009). Approximately $50 \%$ of all eukaryotic proteins are predicted to be glycosylated and this proportion increases substantially with respect to human serum proteins, which are main targets as biopharmaceuticals (Apweiler et al., 1999).
The workhorse for the production of simple proteins is Escherichia coli, the best characterized expression system offering high product yields at low costs (Walsh, 2010a). However, this microorganism is not able to perform some PTMs, which are indispensable for recombinant therapeutical proteins (Kamionka, 2011). Consequently, mammalian cell lines are the preferred expression systems for the production of recombinant glycoproteins, as their protein glycosylation patterns largely resemble those of humans (Schmidt, 2004). Among the mammalian cell lines, Chinese hamster ovary $(\mathrm{CHO})$ cells comprise the leading host system for current biopharmaceuticals, even though several CHO-derived products presented non-human glycosylation (Chung et al., 2008; Hossler et al., 2009; Omasa et al., 2010; Kim et al., 2012).

As higher eukaryotes, plants are able to synthesize complex multimeric proteins and perform PTMs in a similar manner as humans do. Therefore, plants and plant cell cultures are gradually gaining acceptance as production hosts for recombinant biopharmaceuticals. The first plantmade pharmaceutical (PMP) received market approval in 2012 (http://www.protalix.com/products/elelyso-taliglucerase-alfa.asp) and several additional PMPs are being tested in clinical trials (reviewed in Paul and Ma, 2011). The host system for Elelyso ${ }^{\mathrm{TM}}$, a recombinant glucocerebrosidase for the treatment of the lysosomal storage disease Morbus Gaucher, is a carrot-based cell line established by Protalix (Shaaltiel et al., 2007). It is cultured in 
bioreactors based on disposable plastic bags. While other frequently used plant systems like alfalfa, tobacco, and Nicotiana benthamiana need to be grown in greenhouses, bioreactor cultivation is established for the aquatic plant Lemna minor and for the moss Physcomitrella patens (Decker and Reski, 2007; Paul and Ma, 2011; Paul et al., 2013). Within the following sections we will focus on the special features for biopharmaceutical production and achievements within glyco-engineering of the moss system.

\section{MOSS CULTIVATION AND ENGINEERING CHARACTERISTICS}

The non-seed plant $P$. patens, a moss, is a well-established model system for evolutionary and functional genomics approaches (Cove et al., 2006; Menand etal., 2007; Mosquna et al., 2009; Khraiwesh et al., 2010; Sakakibara et al., 2013). It can be grown throughout its complete life cycle under contained conditions in vitro in a simple mineral medium (Frank et al., 2005; Strotbek etal., 2013). The germination of the haploid spores leads to the growth of protonema (Figure 1A), a branched filamentous tissue which comprises two distinct cell types, chloronema and caulonema. Every cell is in direct contact with the culture medium, allowing efficient nutrient uptake and product secretion (Schillberg etal., 2013). This young tissue can be maintained in suspension cultures without any addition of phytohormones, only by mechanical disruption of the filaments. In contrast to immortalized or de-differentiated mammalian or higher-plant cell cultures, which are prone to instability or somaclonal variation (Larkin and Scowcroft, 1981; Xu et al., 2011; Bailey et al., 2012), the fully differentiated protonema tissue is genetically stable (Reutter and Reski, 1996). In the next developmental step, buds differentiating from protonema cells give rise to the adult plant, the leafy gametophore, consisting of shoot-like, leaf-like, and rootlike tissues (Figure 1B). After fertilization of the gametes, the sporophyte, the only diploid tissue in the life cycle of mosses, grows on and is sustained by the gametophore (Reski et al., 1998). In vitro cultivation of all stages can be performed either on agar plates or as suspension cultures in liquid media. The availability of efficient protocols for protoplast isolation (Figure 1C) and transfection (Rother etal., 1994; Strotbek et al., 2013) and an excellent regeneration capacity of single transfected cells to whole plants make genetic engineering of moss a straight-forward and frequently used approach (e.g., Lorenz et al., 2003; Qudeimat et al., 2008; Ludwig-Müller etal., 2009; Mosquna et al., 2009; Khraiwesh et al., 2010; Sakakibara et al., 2013). The created moss strains can be preserved by cryo-conservation (Schulte and Reski, 2004), and thus can serve as Master Cell Banks. The International Moss Stock Center IMSC, a reference center for moss ecotypes and transgenic lines, provides a service for long-term storage (http://www.moss-stock-center.org).

The employment of in vitro axenic plant cell or tissue cultures offers an environment in which contamination with human pathogens is rather unlikely (Schillberg et al., 2013). Moreover, only in these systems culture conditions can be precisely controlled and standardized (Hohe and Reski, 2005), which is essential for the production of pharmaceuticals according to good manufacturing practice (GMP) guidelines (Fischer et al., 2012).

Various scales of highly controllable cultivation devices were developed for Physcomitrella, ranging from simple shaking flasks (Figure 1D) and $5 \mathrm{~L}$ aerated flasks to diverse forms of photobioreactors, including stirred glass tank bioreactors with a volume of up to $15 \mathrm{~L}$ (Figure 1E; Hohe and Reski, 2002) and a modular tubular bioreactor with a working volume of up to 100 L (reviewed in Decker and Reski, 2008, 2012). More recently, disposable wave-bag reactors (Figure 1F) were employed for high-density protein production purposes under full cGMP compliance (www.greenovation.com). Several pharmaceutically interesting proteins have been synthesized in moss bioreactors, among them the growth factors vascular endothelial growth factor (VEGF; Baur et al., 2005) and erythropoietin (EPO; Weise etal., 2007) as well as the first marketed product for research use, human FGF7/keratinocyte growth factor (KGF; www.greenovation.com). In addition, proteins with a function in immune responses like IgGs (Schuster et al., 2007; Kircheis et al., 2012) and the complement-regulatory protein factor H (Büttner-Mainik et al., 2011) were produced in moss. Furthermore, two products for enzyme-replacement

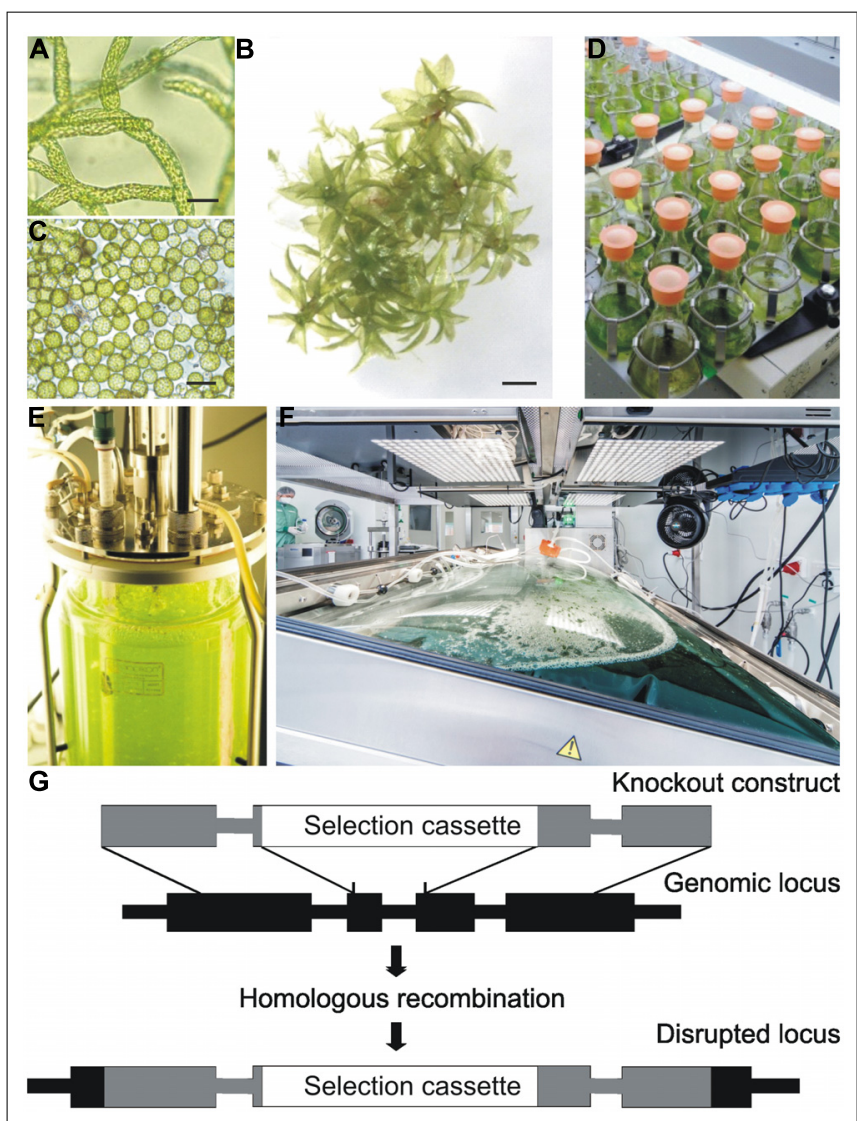

FIGURE 1 | Physcomitrella patens in vitro cultivation and schematic representation of a knockout construct for gene targeting. (A) young filamentous tissue, protonema, ideal for suspension cultures; (B) adult leafy moss plant (gametophore); (C) protoplasts; (D) small scale liquid culture in flasks; (E) stirred tank bioreactor; (F) wave bioreactor (image courtesy of greenovation Biotech $\mathrm{GmbH}$ ); (G) illustration of allele replacement via homologous recombination. The regions homologous to the targeted gene, which are used for the knockout construct, are shown in gray, and the inserted selection cassette is depicted in white. Thick lines represent introns and rectangles exons. Scale bars $50 \mu \mathrm{m}$ (A,B), $500 \mu \mathrm{m}$ (C). 
therapies, human alpha-galactosidase and glucocerebrosidase are expected to reach clinical trial phases by the end of 2014 (www.greenovation.com).

The use of Physcomitrella as a production host for recombinant biopharmaceuticals was facilitated by well-developed molecular toolboxes. Heterologous as well as endogenous promoters were characterized for their suitability to achieve high levels of recombinant product (Horstmann et al., 2004; Weise et al., 2006). In addition, several moss-derived signal peptides were evaluated for improved secretion of the recombinant product to the surrounding medium (Schaaf et al., 2004, 2005; Weise et al., 2006). The moss genome sequence is available since 2008 (Rensing et al., 2008), and together with nearly 400,000 expressed sequence tags (ESTs) obtained from different experimental conditions, tissues, and developmental stages (Nishiyama et al., 2003; Lang et al., 2008) it allows a reliable prediction of gene structures. The internet resource www.cosmoss.org provides access to a high-quality functional annotation including more than 32,000 protein-coding genes (Zimmer et al., 2013). This resource was very convenient for the identification of genes involved in the glycosylation of recombinant proteins synthesized in moss bioreactors.

However, the main driver for moss functional genomics approaches in general and glyco-engineering in particular was the unique accessibility of this organism for gene targeting approaches via homologous recombination. Displaying an exceptionally high rate of homologous recombination in mitotic cells (Strepp et al., 1998; Schaefer, 2001; Hohe et al., 2004; Kamisugi et al., 2006), base-specific precise genetic engineering is feasible with high efficiency. Undesirable gene functions can be completely eliminated by targeted knockout approaches. The knockout construct used for the transfection of moss protoplasts regularly consists of 7001000 bp genomic DNA (homologous regions) flanking each side of a selection cassette, which interrupts or replaces the target gene when indicated (Figure 1G). Glyco-engineering of moss was successfully accomplished by various gene targeting approaches (see below).

\section{PROTEIN GLYCOSYLATION AND MOSS GLYCO-ENGINEERING}

Protein glycosylation is a complex and heterogeneous modification which can be classified in two main categories, Nand $\mathrm{O}$-glycosylation. In the former, the carbohydrates are attached to the amide group of asparagine $(\mathrm{N})$ in the consensus sequence $\mathrm{N}-\mathrm{X}-\mathrm{S} / \mathrm{T}$ (where $\mathrm{X}$ can be any amino acid except proline, and the third amino acid can be either serine or threonine; Mononen and Karjalainen, 1984; Gavel and von Heijne, 1990). O-glycans, on the other hand, are attached to the hydroxyl group of serine (S), threonine (T), hydroxylysine or hydroxyproline (Hyp; Varki et al., 2009). In contrast to $\mathrm{N}$-glycosylation, consensus sequences for O-glycosylation in mammals are not well defined or non-existing (Hansen et al., 1998; Julenius et al., 2005).

$\mathrm{N}$-glycosylation in animals is a largely cell-type and speciesspecific feature (Raju et al., 2000; Croset et al., 2012). Moreover, potential glycosylation sites on a given protein can be either unmodified or occupied by varying glycan structures which result from the maturation of the glycan throughout the endoplasmic reticulum (ER) and the Golgi apparatus (GA), leading to microheterogeneity of glycoproteins (Kolarich et al., 2012). Compared to other higher eukaryotes, plants display more conserved glycan patterns between different species and a less diverse palette of $N$-glycans (Bosch et al., 2013), fascilitating the production of homogeneous glycoproteins.

As higher eukaryotes, plants are able to produce $N$-glycans of the complex type with the core sugar structure Man3GlcNAc2 consisting of two $\mathrm{N}$-acetylglucosamine and three mannose residues that is identical to humans (Lerouge et al., 1998; Wilson, 2002). Up to two terminally attached GlcNAc residues are also common between plant and bi-antennary mammalian complex-type glycoprotein oligosaccharides (reviewed in Gomord et al., 2010). Differing from the human structure, which displays a fucose residue 1,6-linked to the proximal GlcNAc moiety, most plant $N$-glycans carry a $\beta 1,2$ xylose and an $\alpha 1,3$ fucose linked to the glycan core. These sugar structures are common for all land plants analyzed so far, including mosses as the evolutionary oldest group (Koprivova et al., 2003; Viëtor et al., 2003). Their presence raised concerns about plantproduced biopharmaceuticals as they were shown to induce antibody formation in mammals (van Ree et al., 2000; Bardor etal., 2003; Westphal etal., 2003; Bencúrová etal., 2004; Jin et al., 2008). The consequence of an immune response against the pharmaceutical can lead to antibody-mediated reduction of product efficacy as well as to severe clinical complications (Schellekens, 2002).

Consequently, first plant glyco-engineering approaches aimed at targeting the glycosyltransferases responsible for the addition of these two residues. Ten years ago Arabidopsis thaliana as well as moss lines lacking $\beta 1,2$ xylosylation and $\alpha 1,3$ fucosylation have been generated (Koprivova et al., 2004; Strasser et al., 2004). The predominant glycan type of the double knockout moss line for $\beta 1,2$ xylosyltransferase (XylT) and $\alpha 1,3$ fucosyltransferase (FucT) was the GnGn form (GlcNAc2Man3GlcNAc2; Koprivova et al., 2004). A $\Delta$ XylT/FucT genotype is currently in use as genetic background for most of the recombinant products described from moss bioreactors.

Lacking the core fucose, the engineered moss $N$-glycans differ from the human ones which contain an $\alpha 1,6$-linked fucose residue. However, lack of this residue proved to be advantageous for the efficacy of antibodies targeting tumor cells (Shields et al., 2002; Shinkawa et al., 2003; Cox et al., 2006; Schuster et al., 2007). The underlying phenomenon, antibody-dependent cellular cytotoxicity (ADCC), comprises receptor binding and activation of a natural killer cell by an antigen-antibody complex on the target cell surface resulting in lysis of the target cell. Binding and activation of the killer cells was up to $40 \times$ more efficient with a monoclonal antibody produced in glyco-engineered, fucose-lacking moss cells compared to the same antibody produced in $\mathrm{CHO}$ cells (Schuster et al., 2007).

In addition to the GnGn $N$-glycan form, many plant species display $\alpha 1,4$ fucose, and $\beta 1,3$ galactose linked to the terminal GlcNAc residues on one or both of the antennae (Wilson, 2001). This trisaccharide Fuc $\alpha 1-4(\mathrm{Gal} \beta 1-3)$ GlcNAc is known as Lewis A $\left(\mathrm{Le}^{\mathrm{a}}\right)$ structure. It is synthesized by $\beta 1,3$ galactosyltransferases (GalT) and $\alpha 1,4$ fucosyltransferases as the last steps of $N$-glycan 
maturation in the plant GA (reviewed in Gomord et al., 2010). In contrast to the high prevalence of xylose and core fucose residues on plant $N$-glycans, $\mathrm{Le}^{\mathrm{a}}$ structures are found in a much lower proportion (Fitchette-Lainé et al., 1997; Koprivova et al., 2003; Viëtor etal., 2003; Strasser etal., 2007). However, Le ${ }^{\mathrm{a}}$ epitopes were described on recombinant proteins produced in plants (Petruccelli et al., 2006; Weise et al., 2007; Castilho et al., 2013). The production of recombinant human EPO (rhEPO) in both moss and N. benthamiana, lead to proteins decorated with high amounts of Le ${ }^{a}$ structures (Weise et al., 2007; Castilho et al., 2013). Although Le $\mathrm{Le}^{\mathrm{a}}$ epitopes are found in humans as part of the Lewis-positive histo-blood groups (Henry et al., 1995), they are rarely present in healthy adults, but increased in patients with certain types of cancer (Zhang etal., 1994). Furthermore, antibodies against Le ${ }^{\mathrm{a}}$ epitopes are frequent (Wilson et al., 2001). Therefore, it is advisable to remove the respective $\beta 1,3$ galactose and $\alpha 1,4$ fucose residues from plant-produced recombinant products.

A single putative $\alpha 1,4$ fucosyltransferase gene was detected in the moss genome. While the targeted knockout of this gene resulted in the loss of terminal $\alpha 1,4$ fucose residues, $\beta 1,3$-linked galactoses were still present on moss $N$-glycans. In contrast to the singlecopy $\alpha 1,4$ fucosyltransferase gene, 13 putative galt homologs were identified in $P$. patens. Out of these, exclusively one gene (galt1) was shown to be responsible for the synthesis of $\mathrm{Le}^{\mathrm{a}}$ in moss. The disruption of galt1 alone resulted in the absence of the complete Le $^{\mathrm{a}}$ epitope, not only of the galactose residue but also of the terminal fucose, both in the total moss $N$-glycan pool and on the moss-produced rhEPO (Parsons et al., 2012). The absence of the $\alpha 1,4$ fucose in the galt1 knockout line $(\Delta$ galt 1$)$ with intact $\alpha 1,4$ fucosyltransferase activity confirmed that this is the last enzyme in the plant $\mathrm{N}$-glycosylation pathway and that the presence of galactose on the substrate is indispensable for the fucosyltransferase activity (Parsons et al., 2012). The lack of GalT1 activity did not affect the moss growth rate. The homogeneity of the rhEPO glycosylation achieved in the moss galt1 knockout line was remarkable, with almost only one glycosylation form, the aimed core structure with terminal GlcNAc residues (Parsons et al., 2012; Figure 2).

In humans, the GnGn glycan is frequently further elongated with galactose added in $\beta 1,4$ linkage and this is often capped with sialic acid residues. The targeted insertion ("knockin") of the human $\beta 1,4$ galt into the moss genome demonstrated the general feasibility of $\beta 1,4$ galactosylation of moss $N$-glycans (Huether et al., 2005; Parsons et al., 2012). Further terminal elongation of plant $N$-glycans has been demonstrated for N. benthamiana which transiently produced glycoproteins with human-like sialylation (Castilho et al., 2013; Jez et al., 2013). This will be a future task for moss glyco-engineering.

Outstanding success has been achieved so far by engineering plant N-glycosylation patterns for the production of humanized glycoproteins. In contrast, the issue of adverse O-glycosylation in PMPs has not been addressed in the same detail. Concerning plant $O$-glycan engineering, recombinant proteins displaying human so-called mucin-type O-glycosylation were generated recently (Daskalova et al., 2010; Castilho et al., 2012; Yang et al., 2012). In contrast to rather conserved N-glycosylation patterns,

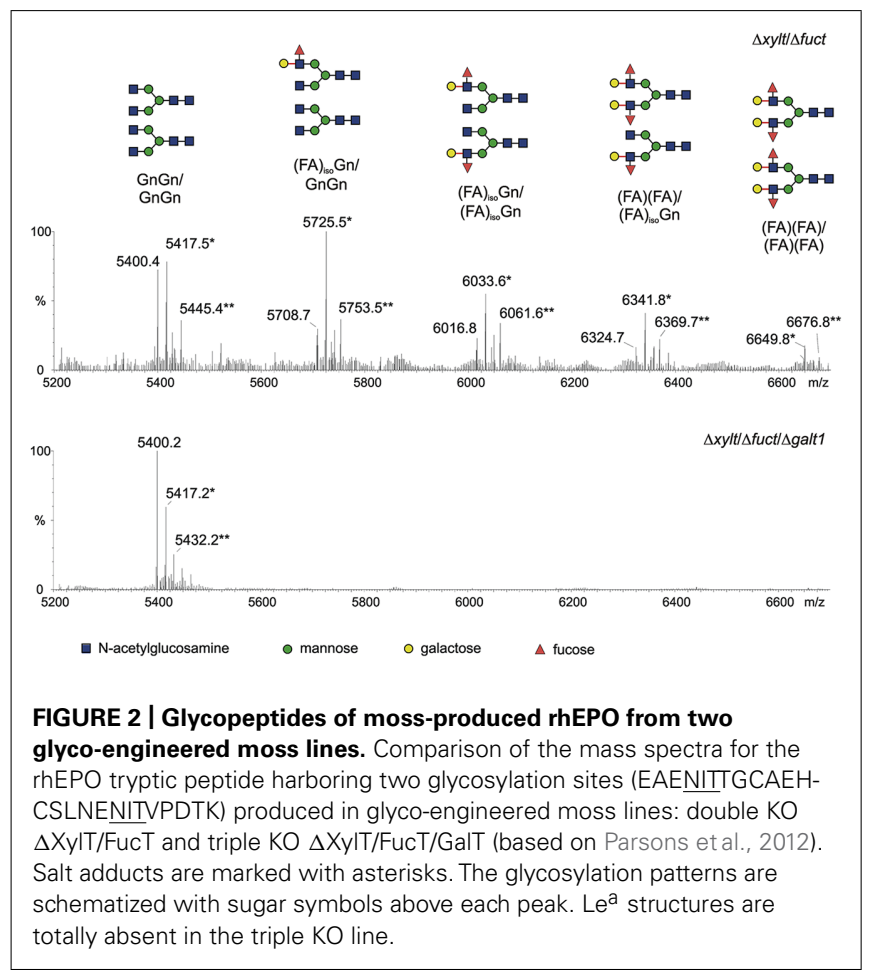

plant-typical O-glycosylation differs fundamentally from the typical human mucin-type O-glycosylation (reviewed by Gomord etal., 2010), and was shown to induce the formation of antibodies (Léonard etal., 2005). In plants, the main attachment site for O-glycosylation is 4-trans-Hyp (reviewed by Showalter, 2001), while no glycosylation of Hyp occurs in animals (Gorres and Raines, 2010). Hyp is generated posttranslationally by prolyl 4-hydroxylases $(\mathrm{P} 4 \mathrm{H})$ via hydroxylation of proline. Prolyl-hydroxylation is a very common modification both in mammals and in plants, though recognition sequences differ. In plants, the target motif for O-glycosylation after $\mathrm{P} 4 \mathrm{H}$-catalyzed hydroxylation, the so-called glycomodules present on Hyp-rich glycoproteins (HRGPs), are defined (Kieliszewski and Lamport, 1994) and validated (Tan etal., 2003; Shimizu etal., 2005). In silico analysis of the human proteome revealed that $30 \%$ of the human proteins bear a recognition sequence for plant P4Hs (Gomord et al., 2010), thus being putative candidates for non-human prolyl-hydroxylation when recombinantly produced in plant-based systems. In fact, undesired plant-typical prolylhydroxylation and in some cases even non-human O-glycosylation of biopharmaceuticals was reported (Karnoup, 2005; Weise et al., 2007; Pinkhasov et al., 2011). The most direct strategy to avoid non-human O-glycosylation in PMPs is the elimination of the anchor Hyp, which itself is an undesired PTM performed by plant $\mathrm{P} 4 \mathrm{H}$ enzymes.

After systematic disruption of each of the six $p 4 h$ genes in Physcomitrella, targeted deletion of $p 4 h 1$ resulted in the complete elimination of the previously reported prolyl-hydroxylation of moss-produced rhEPO (Parsons etal., 2013). As prolylhydroxylation and further glycosylation of plant extracellular matrix and cell wall proteins play important roles for growth, 
cell differentiation, and stress adaption (Lamport et al., 2006; Velasquez et al., 2011) we expected a negative impact on the growth rate of the lines. However, the $\Delta p 4 h 1$ moss lines were not impaired neither in growth or development nor in protein productivity (Parsons et al., 2013).

The ease of gene targeting in moss enabled glyco-engineering approaches for the elimination of any plant-typical immunogenic residues. This provides a plant-based system offering the stable production of safe protein therapeutics.

\section{AUTHOR CONTRIBUTIONS}

Eva L. Decker, Juliana Parsons, and Ralf Reski were involved in gathering and interpretation of data, writing the manuscript and revising the work. Ralf Reski is co-inventor of the moss bioreactor and co-founder of greenovation Biotech. He currently serves as advisory board member of this company. Eva L. Decker, Juliana Parsons, and Ralf Reski are co-inventors of patents and patent applications related to the topic discussed here.

\section{ACKNOWLEDGMENTS}

This work was supported by contract research "Glykobiologie/Glykomik" of the Baden-Württemberg Stiftung and by the Excellence Initiative of the German Federal and State Governments (EXC294 to Ralf Reski). We thank Anne Katrin Prowse for proof-reading of the manuscript.

\section{REFERENCES}

Apweiler, R., Hermjakob, H., and Sharon, N. (1999). On the frequency of protein glycosylation, as deduced from analysis of the SWISS-PROT database. Biochim. Biophys. Acta 1473, 4-8. doi: 10.1016/S0304-4165(99)00165-168

Bailey, L. A., Hatton, D., Field, R., and Dickson, A. J. (2012). Determination of Chinese hamster ovary cell line stability and recombinant antibody expression during long-term culture. Biotechnol. Bioeng. 109, 2093-2103. doi: 10.1002/bit.24485

Bardor, M., Faveeuw, C., Fitchette, A.-C., Gilbert, D., Galas, L., Trottein, F., et al. (2003). Immunoreactivity in mammals of two typical plant glycoepitopes, core $\alpha(1,3)$-fucose and core xylose. Glycobiology 13, 427-434. doi: $10.1093 /$ glycob/cwg024

Baur, A., Reski, R., and Gorr, G. (2005). Enhanced recovery of a secreted recombinant human growth factor using stabilizing additives and by co-expression of human serum albumin in the moss Physcomitrella patens. Plant Biotechnol. J. 3, 331-340. doi: 10.1111/j.1467-7652.2005.00127.x

Bencúrová, M., Hemmer, W., Focke-Tejkl, M., Wilson, I. B. H., and Altmann, F. (2004). Specificity of IgG and IgE antibodies against plant and insect glycoprotein glycans determined with artificial glycoforms of human transferrin. Glycobiology 14, 457-466. doi: 10.1093/glycob/cwh058

Bosch, D., Castilho, A., Loos, A., Schots, A., and Steinkellner, H. (2013). N-glycosylation of plant-produced recombinant proteins. Curr. Pharm. Des. 19, 5503-5512. doi: 10.2174/1381612811319310006

Büttner-Mainik, A., Parsons, J., Jérôme, H., Hartmann, A., Lamer, S., Schaaf, A., et al. (2011). Production of biologically active recombinant human factor $\mathrm{H}$ in Physcomitrella. Plant Biotechnol. J. 9, 373-383. doi: 10.1111/j.14677652.2010.00552.x

Castilho, A., Neumann, L., Daskalova, S., Mason, H. S., Steinkellner, H., Altmann, F., et al. (2012). Engineering of sialylated mucin-type O-glycosylation in plants. J. Biol. Chem. 287, 36518-36526. doi: 10.1074/jbc.M112.402685

Castilho, A., Neumann, L., Gattinger, P., Strasser, R., Vorauer-Uhl, K., Sterovsky, T., et al. (2013). Generation of biologically active multi-sialylated recombinant human EPOFc in plants. PLoS ONE 8:e54836. doi: 10.1371/journal.pone.0054836

Chung, C. H., Mirakhur, B., Chan, E., Le, Q.-T., Berlin, J., Morse, M., et al. (2008). Cetuximab-induced anaphylaxis and IgE specific for galactose- $\alpha$-1,3-galactose. N. Engl. J. Med. 358, 1109-1117. doi: 10.1056/NEJMoa074943

Cove, D., Bezanilla, M., Harries, P., and Quatrano, R. (2006). Mosses as model systems for the study of metabolism and development. Annu. Rev. Plant Biol. 57, 497-520. doi: 10.1146/annurev.arplant.57.032905.105338
Cox, K. M., Sterling, J. D., Regan, J. T., Gasdaska, J. R., Frantz, K. K., Peele, C. G., et al. (2006). Glycan optimization of a human monoclonal antibody in the aquatic plant Lemna minor. Nat. Biotechnol. 24, 1591-1597. doi: 10.1038/ nbt 1260

Croset, A., Delafosse, L., Gaudry, J.-P., Arod, C., Glez, L., Losberger, C., et al. (2012). Differences in the glycosylation of recombinant proteins expressed in HEK and CHO cells. J. Biotechnol. 161, 336-348. doi: 10.1016/j.jbiotec.2012.06.038

Daskalova, S. M., Radder, J. E., Cichacz, Z. A., Olsen, S. H., Tsaprailis, G., Mason, H., et al. (2010). Engineering of N. benthamiana L. plants for production of N-acetylgalactosamine-glycosylated proteins-towards development of a plant-based platform for production of protein therapeutics with mucin type O-glycosylation. BMC Biotechnol. 10:62. doi: 10.1186/1472-6750-10-62

Decker, E. L., and Reski, R. (2007). Moss bioreactors producing improved biopharmaceuticals. Curr. Opin. Biotechnol. 18, 393-398. doi: 10.1016/j.copbio.2007.07.012

Decker, E. L., and Reski, R. (2008). Current achievements in the production of complex biopharmaceuticals with moss bioreactors. Bioprocess. Biosyst. Eng. 31, 3-9. doi: 10.1007/s00449-007-0151-y

Decker, E. L., and Reski, R. (2012). Glycoprotein production in moss bioreactors. Plant Cell Rep. 31, 453-460. doi: 10.1007/s00299-011-1152-1155

Fischer, R., Schillberg, S., Hellwig, S., Twyman, R. M., and Drossard, J. (2012). GMP issues for recombinant plant-derived pharmaceutical proteins. Biotechnol. Adv. 30, 434-439. doi: 10.1016/j.biotechadv.2011.08.007

Fitchette-Lainé, A.-C., Gomord, V., Cabanes, M., Michalski, J.-C., Saint Macary, M., Foucher, B., etal. (1997). N-glycans harboring the Lewis A epitope are expressed at the surface of plant cells. Plant J. 12, 1411-1417. doi: 10.1046/j.1365-313x.1997.12061411.x

Frank, W., Decker, E. L., and Reski, R. (2005). Molecular tools to study Physcomitrella patens. Plant Biol. 7, 220-227. doi: 10.1055/s-2005-865645

Gavel, Y., and von Heijne, G. (1990). Sequence differences between glycosylated and non-glycosylated Asn-X-Thr/Ser acceptor sites: implications for protein engineering. Protein Eng. 3, 433-442. doi: 10.1093/protein/3.5.433

Gomord, V., Fitchette, A.-C., Menu-Bouaouiche, L., Saint-Jore-Dupas, C., Plasson, C., Michaud, D., et al. (2010). Plant-specific glycosylation patterns in the context of therapeutic protein production. Plant Biotechnol. J. 8, 564-587. doi: 10.1111/j.1467-7652.2009.00497.x

Gorres, K. L., and Raines, R. T. (2010). Prolyl 4-hydroxylase. Crit. Rev. Biochem. Mol. Biol. 45, 106-124. doi: 10.3109/10409231003627991

Hansen, J. E., Lund, O., Tolstrup, N., Gooley, A. A., Williams, K. L., and Brunak, S. (1998). NetOglyc: prediction of mucin type O-glycosylation sites based on sequence context and surface accessibility. Glycoconj. J. 15, 115-130. doi: 10.1023/A:1006960004440

Henry, S., Oriol, R., and Samuelsson, B. (1995). Lewis histo-blood group system and associated secretory phenotypes. Vox Sang. 69, 166-182. doi: 10.1111/j.14230410.1995.tb02591.x

Hohe, A., Egener, T., Lucht, J. M., Holtorf, H., Reinhard, C., Schween, G., et al. (2004). An improved and highly standardised transformation procedure allows efficient production of single and multiple targeted gene-knockouts in a moss, Physcomitrella patens. Curr. Genet. 44, 339-347. doi: 10.1007/s00294-0030458-4

Hohe, A., and Reski, R. (2002). Optimisation of a bioreactor culture of the moss Physcomitrella patens for mass production of protoplasts. Plant Sci. 163, 69-74. doi: 10.1016/S0168-9452(02)00059-6

Hohe, A., and Reski, R. (2005). Control of growth and differentiation of bioreactor cultures of Physcomitrella by environmental parameters. Plant Cell Tissue Organ Cult. 81, 307-311. doi: 10.1007/s11240-004-6656-z

Horstmann, V., Huether, C. M., Jost, W., Reski, R., and Decker, E. L. (2004). Quantitative promoter analysis in Physcomitrella patens: a set of plant vectors activating gene expression within three orders of magnitude. BMC Biotechnol. 4:13. doi: $10.1186 / 1472-6750-4-13$

Hossler, P., Khattak, S. F., and Li, Z. J. (2009). Optimal and consistent protein glycosylation in mammalian cell culture. Glycobiology 19, 936-949. doi: 10.1093/glycob/cwp079

Huether, C. M., Lienhart, O., Baur, A., Stemmer, C., Gorr, G., Reski, R., et al. (2005). Glyco-engineering of moss lacking plant-specific sugar residues. Plant Biol. 7, 292-299. doi: 10.1055/s-2005-837653

Jez, J., Castilho, A., Grass, J., Vorauer-Uhl, K., Sterovsky, T., Altmann, F., et al. (2013). Expression of functionally active sialylated human erythropoietin in plants. Biotechnol. J. 8, 371-382. doi: 10.1002/biot.201200363 
Jin, C., Altmann, F., Strasser, R., Mach, L., Schähs, M., Kunert, R., et al. (2008). A plant-derived human monoclonal antibody induces an anti-carbohydrate immune response in rabbits. Glycobiology 18, 235-241. doi: 10.1093/gly$\mathrm{cob} / \mathrm{cwm} 137$

Julenius, K., Mølgaard, A., Gupta, R., and Brunak, S. (2005). Prediction, conservation analysis, and structural characterization of mammalian mucin-type O-glycosylation sites. Glycobiology 15, 153-164. doi: 10.1093/glycob/cwh151

Kamionka, M. (2011). Engineering of therapeutic proteins production in Escherichia coli. Curr. Pharm. Biotechnol. 12, 268-274. doi: 10.2174/138920111794295693

Kamisugi, Y., Schlink, K., Rensing, S. A., Schween, G., von Stackelberg, M., Cuming, A. C., et al. (2006). The mechanism of gene targeting in Physcomitrella patens: homologous recombination, concatenation and multiple integration. Nucleic Acids Res. 34, 6205-6214. doi: 10.1093/nar/gkl832

Karnoup, A. S. (2005). O-linked glycosylation in maize-expressed human IgA1. Glycobiology 15, 965-981. doi: 10.1093/glycob/cwi077

Khraiwesh, B., Arif, M. A., Seumel, G. I., Ossowski, S., Weigel, D., Reski, R., et al. (2010). Transcriptional control of gene expression by microRNAs. Cell 140, 111122. doi: $10.1016 /$ j.cell.2009.12.023

Kieliszewski, M. J., and Lamport, D. T. A. (1994). Extensin: repetitive motifs, functional sites, post-translational codes, and phylogeny. Plant J. 5, 157-172. doi: 10.1046/j.1365-313X.1994.05020157.x

Kim, J. Y., Kim, Y.-G., and Lee, G. M. (2012). CHO cells in biotechnology for production of recombinant proteins: current state and further potential. Appl. Microbiol. Biotechnol. 93, 917-930. doi: 10.1007/s00253-011-3758-3755

Kircheis, R., Halanek, N., Koller, I., Jost, W., Schuster, M., Gorr, G., et al (2012). Correlation of ADCC activity with cytokine release induced by the stably expressed, glyco-engineered humanized Lewis Y-specific monoclonal antibody MB314. MAbs 4, 532-541. doi: 10.4161/mabs.20577

Kolarich, D., Jensen, P. H., Altmann, F., and Packer, N. H. (2012). Determination of site-specific glycan heterogeneity on glycoproteins. Nat. Protoc. 7, 1285-1298. doi: $10.1038 /$ nprot.2012.062

Koprivova, A., Altmann, F., Gorr, G., Kopriva, S., Reski, R., and Decker, E. L. (2003). $\mathrm{N}$-glycosylation in the moss Physcomitrella patens is organized similarly to that in higher plants. Plant Biol. 5, 582-591. doi: 10.1055/s-2003-44721

Koprivova, A., Stemmer, C., Altmann, F., Hoffmann, A., Kopriva, S., Gorr, G., et al. (2004). Targeted knockouts of Physcomitrella lacking plantspecific immunogenic N-glycans. Plant Biotechnol. J. 2, 517-523. doi: 10.1111/j.1467-7652.2004.00100.x

Lamport, D. T., Kieliszewski, M. J., and Showalter, A. M. (2006). Salt stress upregulates periplasmic arabinogalactan proteins: using salt stress to analyse AGP function. New Phytol. 169, 479-492. doi: 10.1111/j.1469-8137.2005.01591.x

Lang, D., Zimmer, A. D., Rensing, S. A., and Reski, R. (2008). Exploring plant biodiversity: the Physcomitrella genome and beyond. Trends Plant Sci. 13, 542549. doi: 10.1016/j.tplants.2008.07.002

Larkin, P. J., and Scowcroft, W. R. (1981). Somaclonal variation-a novel source of variability from cell cultures for plant improvement. Theor. Appl. Genet. 60 197-214. doi: 10.1007/BF02342540

Léonard, R., Lhernould, S., Carlué, M., Fleurat, P., Maftah, A., and Costa, G. (2005). Biochemical characterization of Silene alba $\alpha 4$-fucosyltransferase and Lewis a products. Glycoconj. J. 22, 71-78. doi: 10.1007/s10719-005-0404-404

Lerouge, P., Cabanes-Macheteau, M., Rayon, C., Fischette-Lainé, A.-C., Gomord, V., and Faye, L. (1998). N-glycoprotein biosynthesis in plants: recent developments and future trends. Plant Mol. Biol. 38, 31-48. doi: 10.1023/A:10060120 05654

Li, H., and d'Anjou, M. (2009). Pharmacological significance of glycosylation in therapeutic proteins. Curr. Opin. Biotechnol. 20, 678-684. doi: 10.1016/j.copbio.2009.10.009

Lorenz, S., Tintelnot, S., Reski, R., and Decker, E. L. (2003). Cyclin D-knockout uncouples developmental progression from sugar availability. Plant Mol. Biol. 53 , 227-236. doi: 10.1023/B:PLAN.0000009295.07016.87

Ludwig-Müller, J., Jülke, S., Bierfreund, N. M., Decker, E. L., and Reski, R. (2009). Moss (Physcomitrella patens) GH3 proteins act in auxin homeostasis. New Phytol. 181, 323-338. doi: 10.1111/j.1469-8137.2008.02677.x

Mann, M., and Jensen, O. N. (2003). Proteomic analysis of post-translational modifications. Nat. Biotechnol. 21, 255-261. doi: 10.1038/nbt0303-255

Menand, B., Yi, K., Jouannic, S., Hoffmann, L., Ryan, E., Linstead, P., et al. (2007). An ancient mechanism controls the development of cells with a rooting function in land plants. Science 316, 1477-1480. doi: 10.1126/science. 1142618
Mononen, I., and Karjalainen, E. (1984). Structural comparison of protein sequences around potential N-glycosylation sites. Biochim. Biophys. Acta 788, 364-367. doi: 10.1016/0167-4838(84)90050-90055

Mosquna, A., Katz, A., Decker, E. L., Rensing, S. A., Reski, R., and Ohad, N. (2009). Regulation of stem cell maintenance by the Polycomb protein FIE has been conserved during land plant evolution. Development 136, 2433-2444. doi: $10.1242 /$ dev. 035048

Nishiyama, T., Fujita, T., Shin-I, T., Seki, M., Nishide, H., Uchiyama, I., et al. (2003). Comparative genomics of Physcomitrella patens gametophytic transcriptome and Arabidopsis thaliana: implication for land plant evolution. Proc. Natl. Acad. Sci. U.S.A. 100, 8007-8012. doi: 10.1073/pnas.0932694100

Omasa, T., Onitsuka, M., and Kim, W.-D. (2010). Cell engineering and cultivation of Chinese hamster ovary (CHO) cells. Curr. Pharm. Biotechnol. 11, 233-240. doi: $10.2174 / 138920110791111960$

Parsons, J., Altmann, F., Arrenberg, C. K., Koprivova, A., Beike, A. K., Stemmer, C., et al. (2012). Moss-based production of asialo-erythropoietin devoid of Lewis A and other plant-typical carbohydrate determinants. Plant Biotechnol. J. 10, 851-861. doi: 10.1111/j.1467-7652.2012.00704.x

Parsons, J., Altmann, F., Graf, M., Stadlmann, J., Reski, R., and Decker, E. L. (2013). A gene responsible for prolyl-hydroxylation of moss-produced recombinant human erythropoietin. Sci. Rep. 3:3019. doi: 10.1038/srep03019

Paul, M., and Ma, J. K.-C. (2011). Plant-made pharmaceuticals: leading products and production platforms. Biotechnol. Appl. Biochem. 58, 58-67. doi: 10.1002/bab.6

Paul, M. J., Teh, A. Y., Twyman, R. M., and Ma, J. K. (2013). Target product selection-where can molecular pharming make the difference? Curr. Pharm. Des. 19, 5478-5485. doi: 10.2174/1381612811319310003

Petruccelli, S., Otegui, M. S., Lareu, F., Tran Dinh, O., Fitchette, A.-C., Circosta, A., et al. (2006). A KDEL-tagged monoclonal antibody is efficiently retained in the endoplasmic reticulum in leaves, but is both partially secreted and sorted to protein storage vacuoles in seeds. Plant Biotechnol. J. 4, 511-527. doi: 10.1111/j.1467-7652.2006.00200.x

Pinkhasov, J., Alvarez, M. L., Rigano, M. M., Piensook, K., Larios, D., Pabst, M., etal. (2011). Recombinant plant-expressed tumour-associated MUC1 peptide is immunogenic and capable of breaking tolerance in MUC1.Tg mice. Plant Biotechnol. J. 9, 991-1001. doi: 10.1111/j.1467-7652.2011. 00614.x

Qudeimat, E., Faltusz, A. M. C., Wheeler, G., Lang, D., Holtorf, H., Brownlee, C., et al. (2008). A PIIB-type $\mathrm{Ca}^{2+}$-ATPase is essential for stress adaptation in Physcomitrella patens. Proc. Natl. Acad. Sci. U.S.A. 105, 19555-19560. doi: 10.1073/pnas. 0800864105

Raju, T. S., Briggs, J. B., Borge, S. M., and Jones, A. J. S. (2000). Speciesspecific variation in glycosylation of IgG: evidence for the species-specific sialylation and branch-specific galactosylation and importance for engineering recombinant glycoprotein therapeutics. Glycobiology 10, 477-486. doi: $10.1093 / \mathrm{glycob} / 10.5 .477$

Rensing, S. A., Lang, D., Zimmer, A. D., Terry, A., Salamov, A., Shapiro, H., et al. (2008). The Physcomitrella genome reveals evolutionary insights into the conquest of land by plants. Science 319, 64-69. doi: 10.1126/science.1150646

Reski, R., Reynolds, S., Wehe, M., Kleber-Janke, T., and Kruse, S. (1998). Moss (Physcomitrella patens) expressed sequence tags include several sequences which are novel for plants. Bot. Acta 111, 143-149. doi: 10.1111/j.14388677.1998.tb00689.x

Reutter, K., and Reski, R. (1996). Production of a heterologous protein in bioreactor cultures of fully differentiated moss plants. Plant Tissue Cult. Biotechnol. 2, 142147.

Rother, S., Hadeler, B., Orsini, J. M., Abel, W. O., and Reski, R. (1994). Fate of a mutant macrochloroplast in somatic hybrids. J. Plant Physiol. 143, 72-77. doi: 10.1016/S0176-1617(11)82099-7

Sakakibara, K., Ando, S., Yip, H. K., Tamada, Y., Hiwatashi, Y., Murata, T., et al. (2013). KNOX2 genes regulate the haploid-to-diploid morphological transition in land plants. Science 339, 1067-1070. doi: 10.1126/science. 1230082

Schaaf, A., Reski, R., and Decker, E. L. (2004). A novel aspartic proteinase is targeted to the secretory pathway and to the vacuole in the moss Physcomitrella patens. Eur. J. Cell Biol. 83, 145-152. doi: 10.1078/0171-9335-00371

Schaaf, A., Tintelnot, S., Baur, A., Reski, R., Gorr, G., and Decker, E. L. (2005). Use of endogenous signal sequences for transient production and efficient secretion 
by moss (Physcomitrella patens) cells. BMC Biotechnol. 5:30. doi: 10.1186/14726750-5-30

Schaefer, D. G. (2001). Gene targeting in Physcomitrella patens. Curr. Opin. Plant Biol. 4, 143-150. doi: 10.1016/S1369-5266(00)00150-153

Schellekens, H. (2002). Bioequivalence and the immunogenicity of biopharmaceuticals. Nat. Rev. Drug Discov. 1, 457-462. doi: 10.1038/nrd818

Schillberg, S., Raven, N., Fischer, R., Twyman, R. M., and Schiermeyer, A. (2013). Molecular farming of pharmaceutical proteins using plant suspension cell and tissue cultures. Curr. Pharm. Des. 19, 5531-5542. doi: $10.2174 / 1381612811319310008$

Schmidt, F. R. (2004). Recombinant expression systems in the pharmaceutical industry. Appl. Microbiol. Biotechnol. 65, 363-372. doi: 10.1007/s00253-004-1656-1659

Schulte, J., and Reski, R. (2004). High throughput cryopreservation of 140,000 Physcomitrella patens mutants. Plant Biol. 6, 119-127. doi: 10.1055/s-2004817796

Schuster, M., Jost, W., Mudde, G. C., Wiederkum, S., Schwager, C., Janzek, E., et al. (2007). In vivo glyco-engineered antibody with improved lytic potential produced by an innovative non-mammalian expression system. Biotechnol. J. 2, 700-708. doi: 10.1002/biot.200600255

Shaaltiel, Y., Bartfeld, D., Hashmueli, S., Baum, G., Brill-Almon, E., Galili, G., et al. (2007). Production of glucocerebrosidase with terminal mannose glycans for enzyme replacement therapy of Gaucher's disease using a plant cell system. Plant Biotechnol. J. 5, 579-590. doi: 10.1111/j.1467-7652.2007. 00263.x

Shields, R. L., Lai, J., Keck, R., O’Connell, L. Y., Hong, K., Meng, Y. G., et al. (2002). Lack of fucose on human IgG1 N-linked oligosaccharide improves binding to human FcyRIII and antibody-dependent cellular toxicity. J. Biol. Chem. 277, 26733-26740. doi: 10.1074/jbc.M202069200

Shimizu, M., Igasaki, T., Yamada, M., Yuasa, K., Hasegawa, J., Kato, T., et al. (2005). Experimental determination of proline hydroxylation and hydroxyproline arabinogalactosylation motifs in secretory proteins. Plant J. 42, 877-889. doi: 10.1111/j.1365-313X.2005.02419.x

Shinkawa, T., Nakamura, K., Yamane, N., Shoji-Hosaka, E., Kanda, Y., Sakurada, M., et al. (2003). The absence of fucose but not the presence of galactose or bisecting $\mathrm{N}$-acetylglucosamine of human IgG1 complex-type oligosaccharides shows the critical role of enhancing antibody-dependent cellular cytotoxicity. J. Biol. Chem. 278, 3466-3473. doi: 10.1074/jbc.M210665200

Showalter, A. M. (2001). Arabinogalactan-proteins: structure, expression and function. Cell. Mol. Life Sci. 58, 1399-1417. doi: 10.1007/PL00000784

Strasser, R., Altmann, F., Mach, L., Glössl, J., and Steinkellner, H. (2004). Generation of Arabidopsis thaliana plants with complex N-glycans lacking $\beta 1,2$ linked xylose and core $\alpha 1,3$-linked fucose. FEBS Lett. 561, 132-136. doi: 10.1016/S0014-5793(04)00150-4

Strasser, R., Bondili, J. S., Vavra, U., Schoberer, J., Svoboda, B., Glössl, J., et al. (2007). A unique $\beta 1,3$-galactosyltransferase is indispensable for the biosynthesis of N-glycans containing Lewis A structures in Arabidopsis thaliana. Plant Cell Online 19, 2278-2292. doi: 10.1105/tpc.107.052985

Strepp, R., Scholz, S., Kruse, S., Speth, V., and Reski, R. (1998). Plant nuclear gene knockout reveals a role in plastid division for the homolog of the bacterial cell division protein FtsZ, an ancestral tubulin. Proc. Natl. Acad. Sci. U.S.A. 95, 4368-4373. doi: 10.1073/pnas.95.8.4368

Strotbek, C., Krinninger, S., and Frank, W. (2013). The moss Physcomitrella patens: methods and tools from cultivation to targeted analysis of gene function. Int. J. Dev. Biol. 57, 553-564. doi: 10.1387/ijdb.130189wf

Tan, L., Leykam, J. F., and Kieliszewski, M. J. (2003). Glycosylation motifs that direct arabinogalactan addition to arabinogalactan-proteins. Plant Physiol. 132, 1362-1369. doi: 10.1104/pp.103.021766

van Ree, R., Cabanes-Macheteau, M., Akkerdaas, J., Milazzo, J.-P., Loutelier-Bourhis, C., Rayon, C., et al. (2000). $\beta(1,2)$-xylose and $\alpha(1,3)$-fucose residues have a strong contribution in IgE binding to plant glycoallergens. J. Biol. Chem. 275, 1145111458. doi: 10.1074/jbc.275.15.11451

Varki, A., Cummings, R. D., Esko, J. D., Freeze, H. H., Stanley, P., Bertozzi, C. R., et al. (2009). Essentials of Glycobiology, 2nd Edn. Cold Spring Harbor, NY: Cold Spring Harbor Laboratory Press.
Velasquez, S. M., Ricardi, M. M., Dorosz, J. G., Fernandez, P. V., Nadra, A. D., PolFachin, L., et al. (2011). O-glycosylated cell wall proteins are essential in root hair growth. Science 332, 1401-1403. doi: 10.1126/science.1206657

Viëtor, R., Loutelier-Bourhis, C., Fitchette, A.-C., Margerie, P., Gonneau, M., Faye, L., et al. (2003). Protein N-glycosylation is similar in the moss Physcomitrella patens and in higher plants. Planta 218, 269-275. doi: 10.1007/s00425-003-1099-Z

Walsh, G. (2010a). Biopharmaceutical benchmarks 2010. Nat. Biotechnol. 28, 917924. doi: 10.1038/nbt0910-917

Walsh, G. (2010b). Post-translational modifications of protein biopharmaceuticals. Drug Discov. Today 15, 773-780. doi: 10.1016/j.drudis.2010.06.009

Walsh, G., and Jefferis, R. (2006). Post-translational modifications in the context of therapeutic proteins. Nat. Biotechnol. 24, 1241-1252. doi: 10.1038/nbt1252

Weise, A., Altmann, F., Rodriguez-Franco, M., Sjoberg, E. R., Bäumer, W., Launhardt, H., et al. (2007). High-level expression of secreted complex glycosylated recombinant human erythropoietin in the Physcomitrella $\Delta$-fuc-t $\Delta$-xyl-t mutant. Plant Biotechnol. J. 5, 389-401. doi: 10.1111/j.1467-7652.2007.00248.x

Weise, A., Rodriguez-Franco, M., Timm, B., Hermann, M., Link, S., Jost, W., et al. (2006). Use of Physcomitrella patens actin $5^{\prime}$ regions for high transgene expression: importance of $5^{\prime}$ introns. Appl. Microbiol. Biotechnol. 70, 337-345. doi: 10.1007/s00253-005-0087-86

Westphal, S., Kolarich, D., Foetisch, K., Lauer, I., Altmann, F., Conti, A., et al. (2003). Molecular characterization and allergenic activity of Lyc e 2 ( $\beta$-fructofuranosidase), a glycosylated allergen of tomato. Eur. J. Biochem. 270, 1327-1337. doi: 10.1046/j.1432-1033.2003.03503.x

Wilson, I. B. H. (2001). Identification of a cDNA encoding a plant Lewis-type $\alpha 1,4$-fucosyltransferase. Glycoconj. J. 18, 439-447. doi: 10.1023/A:1016030000527 Wilson, I. B. H. (2002). Glycosylation of proteins in plants and invertebrates. Curr. Opin. Struct. Biol. 12, 569-577. doi: 10.1016/S0959-440X(02)00367-366

Wilson, I. B. H., Zeleny, R., Kolarich, D., Staudacher, E., Stroop, C. J. M., Kamerling, J. P., et al. (2001). Analysis of Asn-linked glycans from vegetable foodstuffs: widespread occurrence of Lewis A, core $\alpha 1,3$-linked fucose and xylose substitutions. Glycobiology 11, 261-274. doi: 10.1093/glycob/11.4.261

Xu, X., Nagarajan, H., Lewis, N. E., Pan, S., Cai, Z., Liu, X., et al. (2011). The genomic sequence of the Chinese hamster ovary (CHO)-K1 cell line. Nat. Biotechnol. 29, 735-741. doi: 10.1038/nbt.1932

Yang, Z., Bennett, E. P., Jørgensen, B., Drew, D. P., Arigi, E., Mandel, U., et al. (2012). Toward stable genetic engineering of human O-glycosylation in plants. Plant Physiol. 160, 450-463. doi: 10.1104/pp.112.198200

Zhang, K., Baeckström, D., and Hansson, G. C. (1994). A secreted mucin carrying Sialyl-Lewis A from colon carcinoma cells binds to E-selectin and inhibits HL-60 cell adhesion. Int. J. Cancer 59, 823-829. doi: 10.1002/ijc.2910590619

Zimmer, A. D., Lang, D., Buchta, K., Rombauts, S., Nishiyama, T., Hasebe, M., et al. (2013). Reannotation and extended community resources for the genome of the non-seed plant Physcomitrella patens provide insights into the evolution of plant gene structures and functions. BMC Genomics 14:498. doi: 10.1186/1471-216414-498

Conflict of Interest Statement: The authors declare that the research was conducted in the absence of any commercial or financial relationships that could be construed as a potential conflict of interest.

Received: 28 May 2014; paper pending published: 16 June 2014; accepted: 27 June 2014; published online: 09 July 2014.

Citation: Decker EL, Parsons J and Reski R (2014) Glyco-engineering for biopharmaceutical production in moss bioreactors. Front. Plant Sci. 5:346. doi: 10.3389/fpls. 2014.00346

This article was submitted to Plant Physiology, a section of the journal Frontiers in Plant Science.

Copyright $(92014$ Decker, Parsons and Reski. This is an open-access article distributed under the terms of the Creative Commons Attribution License (CC BY). The use, distribution or reproduction in other forums is permitted, provided the original author(s) or licensor are credited and that the original publication in this journal is cited, in accordance with accepted academic practice. No use, distribution or reproduction is permitted which does not comply with these terms. 